\title{
Conventional versus genomic selection for white spruce improvement: a comparison of costs and benefits of plantations on Quebec public lands
}

\author{
Vincent Chamberland ${ }^{1} \cdot$ François Robichaud $^{2} \cdot$ Martin Perron $^{3} \cdot$ Nancy Gélinas $^{1}$ • Jean Bousquet ${ }^{1,4}$. \\ Jean Beaulieu ${ }^{1,4}$ (iD
}

Received: 14 June 2019 / Revised: 7 November 2019 / Accepted: 18 November 2019 / Published online: 4 January 2020

(C) The Author(s) 2020

\begin{abstract}
Intensive plantation forestry is a potent strategy for forest managers to increase wood production on a smaller forest land acreage, especially with the use of genetically improved reforestation stock. The main drawback with conventional conifer improvement is the several decades it takes before stock deployment, which is particularly acute in the context of climate change and evolving wood markets. Use of genomic selection allows to drastically shorten breeding cycles, resulting in more flexibility and potentially increasing benefits. This study compares the financial performance of five white spruce (Picea glauca) breeding and deployment scenarios, from conventional breeding to genomic selection in conjunction with top-grafting or the use of somatic embryogenesis, in the context of plantations established by the Quebec government on public lands with banned herbicide use. We estimated the land expectation value (LEV) for the five scenarios applied to eight site productivity indices, and considered costs and revenues from breeding, plantation establishment, silviculture, and harvest. LEVs at $4 \%$ discount rate were positive for all scenarios on all site indices, and varied from $\$ 197$ to $\$ 2015 \mathrm{ha}^{-1}$ assuming mechanical brushing of the plantations. The scenarios integrating genomic selection resulted in the highest LEVs, which increased with site index. We also conducted sensitivity analyses with $3 \%$ and $5 \%$ discount rates, with a range of costs and benefits, and with herbicide control of competing vegetation. These results should help orientate public investment decisions regarding the integration of genomic selection at the operational level in tree breeding and reforestation programs on public lands.
\end{abstract}

Keywords Herbicides · Intensive plantation forestry · Picea glauca Somatic embryogenesis · Tree breeding · Financial performance

Communicated by C. Kulheim

Electronic supplementary material The online version of this article (https://doi.org/10.1007/s11295-019-1409-7) contains supplementary material, which is available to authorized users.

Jean Beaulieu

jean.beaulieu@sbf.ulaval.ca

1 Département des sciences du bois et de la forêt, Faculté de foresterie, de géographie et de géomatique, Université Laval, 2405, rue de la Terrasse, QC, Québec G1V 0A6, Canada

2 Forest Economic Advisors LLC, 298 Great Road, Littleton, MA, 01460, USA, and FPInnovations, 1055 rue du P.E.P.S,

QC, Québec G1V 4C7, Canada
3 Direction de la recherche forestière, Ministère des Forêts, de la Faune et des Parcs du Québec, 2700 rue Einstein, QC, Québec G1P 3W8, Canada

4 Canada Research Chair in Forest Genomics, Forest Research Centre and Institute of Systems and Integrative Biology, Faculté de foresterie, de géographie et de géomatique, Université Laval, 1030 avenue de la Médecine, QC, Québec G1V 0A6, Canada 


\section{Introduction}

In Canada and in the province of Quebec in particular, genetically improved seeds from first-generation and secondgeneration seed orchards are now available for reforestation for many conifers, including several spruce species. However, one of the main limitations with conventional conifer improvement is the long breeding cycles necessary to make selections and reach the production stage, which can attain more than 25 years for boreal conifers (Mullin et al. 2011). In the context of climate change and ever changing needs of wood product markets, such long delays become even more a limitation for improving forest stocks in a timely manner for the various needs.

Recent technological developments in tree improvement make it possible to drastically shorten breeding cycles and deployment of genetically improved reforestation stock for long-lived conifers such as spruces. The most significant reduction in length of breeding cycle while maximizing genetic gain is possible with the combination of genomic selection (GS) and somatic embryogenesis (SE) (Park et al. 2016).

Genomic selection is a method proposed by Meuwissen et al. (2001) to estimate the breeding and genetic values of individuals for any quantitative trait such as growth or wood quality using their genomic profiles. The assumption of these authors was that with genome-wide distributed markers, it is possible to capture all the variation in a given trait from effects of each gene involved in the control of this trait. This landmark paper opened the way to numerous studies on genomic selection in a variety of animal and plant species, including trees. In agriculture, advocacy groups such as Greenpeace have well supported the use of genomics-assisted selection methods (Vogel 2009). The first studies on the development and application of GS in spruces were for growth and wood traits in white spruce (Picea glauca [Moench] Voss) (Beaulieu et al. 2014a, 2014b), interior spruce (Picea engelmannii $\times$ glauca complex) (Gamal El-Dien et al. 2015), black spruce (Picea mariana [Mill.] B.S.P.) (Lenz et al. 2017), and Norway spruce (Picea abies [L.] Karst.) (Chen et al. 2018; Lenz et al. 2019). These studies demonstrated that GS was highly efficient in small populations such as the breeding populations developed and maintained by tree breeders. They also showed that the breeding and genetic values of individuals can be predicted at the seed or seedling stage, making it possible to select superior parents or individuals for the traits of interest at a very early age and without having to resort to long-lasting field testing, at least for the current generation.

As for somatic embryogenesis, it is the most powerful vegetative propagation method to capture genetic gain because all components of genetic superiority can be preserved, and because SE cultures can be maintained in a juvenile state indefinitely by cryopreservation in order to ensure the deployment of improved reforestation stock over long periods of time
(Klimaszewska et al. 2007; Bonga 2016). However, the cost of SE-derived plant production can be up to 10 times more expensive than that of seedlings (Sorensson 2006; LeluWalter et al. 2013), which is explained by the fact that SE is still a labor-intensive technique (Cervelli and Senaratna 1995). Due to limitations in production capacity and as a cost reduction strategy, seedling producers such as the Quebec government often combines SE with the production of rooted cuttings, but the costs remain at least twice those of the production of seedlings of the same size from seeds (S. Carles, Ministère des Forêts, de la Faune et des Parcs du Québec, personal communication). Thus, without considering other benefits that clonal forestry could generate, the promise of shorter breeding cycles at the expense of increased plant production costs inevitably raises the question of the actual benefits, or lack thereof, of using GS in various deployment scenarios of plantation forestry under intensive silviculture. As such, it would be also worth testing the costs and benefits of GS in other contexts, such as with less expensive seed and seedling production means relying on sexual reproduction. Indeed, seedlings originating from seed orchards could be used at a larger reforestation scale than multiclonal plantations in all forest management regimes and forest certification programs. Thus, this would significantly help reduce the amortization of research and development investment per hectare.

Tree improvement programs are generally considered as financially justified (Ahtikoski et al. 2012). Greater yields are obtained through increased investments which are usually justified, even in a context of low genetic gain (Ahtikoski et al. 2013). In a recent review, Jansson et al. (2017) presented examples of several studies that have reported economic gains from tree breeding programs in Nordic countries and in other regions of the world.

Published economic studies specific to tree breeding and the use of genomic selection are still scarce. McKenney et al. (1992) compared black spruce and jack pine (Pinus banksiana Lamb.) conventional breeding programs and seed orchards production means using a cost-benefit analysis. They concluded that benefits were higher on most productive sites with the fastest growing species. Benefits also depended on stumpage value, the size of planting program, the magnitude of the genetic gain, and the discount rate. Petrinovic et al. (2009) integrated genetic gains for volume from tree breeding in their analysis focusing on white spruce plantation forestry and estimated the benefits of conventional breeding, multifamily varieties from controlled crosses, and multiclonal varieties produced with somatic embryogenesis but without reduction of the breeding cycle. They reported that the benefits were influenced in descending order by the site quality, the breeding and deployment scenario, and the silvicultural regime. However, these authors considered only stumpage values in their comparisons, without taking account of the differences in silvicultural costs between their various tree 
breeding and deployment scenarios. Recently, Chang et al. (2019) compared the benefits of genomic selection versus those of conventional breeding for white spruce and lodgepole pine (Pinus contorta Dougl. var. latifolia Engelm.) in Alberta using a financial analysis. Their reference year for evaluation was the establishment of the third-generation seed orchard. They used a provincial GYPSY model to project the expected yield for regenerated unimproved stands in Alberta as a base case, and this on three different site indices. The authors assumed $30 \%$ gain in volume for conventional breeding over wild seed and an additional 0-20\% volume gain for genomic selection. The authors found that the use of genomic-selected third-generation planting stock (18-year cycle with seed produced in seed orchards) was difficult to justify on an economical basis only, when compared with conventional breeding (33-year cycle with seed produced in seed orchards) under the current sawlog market value, but a sensitivity analysis revealed that the GS approach was more financially supported at lower discount rates and through an increase in log price premiums at harvesting. Although not relying on strict financial analysis per se, Li and Dungey (2018) reported results of a study on the expected benefits of genomic selection over conventional forward selection in conifer breeding and deployment, using stochastic simulations. They considered various methods to speed up the deployment of selected material, including top-grafting onto mature seed orchard ortets, somatic embryogenesis, and clonal propagation. They showed that deploying clones to produce improved propagules always resulted in higher additional genetic gains than deploying seedlings for the same purpose and that the best option was to select material using genomic selection in combination with using top-grafting for production of improved seed.

The objective of the present study was to compare the financial performance of various breeding and deployment scenarios implicating genomic selection or not, in the context of intensively managed plantations of white spruce on public lands. White spruce is one of the most reforested species in Quebec, with in excess of 30 million up to 40 million seedlings forecasted to be planted every year by the Quebec government on public lands. It is also widely planted in other regions of Canada such as in Alberta and the Maritimes region. In Quebec, it has been the subject of large conventional breeding efforts over the past 30 to 40 years (Corriveau et al. 1991; Beaulieu 1996; Mullin et al. 2011) and, more recently, the subject of intensive efforts to develop and apply GS as a mean to hasten the deployment of improved propagules (Beaulieu et al. 2014a, 2014b; Park et al. 2016; Lenz et al. 2019). The five breeding and deployment scenarios that we tested varied from improved seeds produced in seed orchards and derived from conventional breeding to forward GS with topgrafting in existing seed orchards or with production of SE-derived plants following selection of SE lines with
GS. In comparing these scenarios, we also took into account direct costs and benefits derived from plantations under intensive silviculture, from breeding efforts to plantation establishment to final harvest.

\section{Materials and methods}

To carry out financial assessments of various breeding and deployment scenarios in the context of white spruce plantation under intensive silviculture on public lands, we built a simulation model that made it possible to estimate the yield at any given age of a hectare of plantation to which were applied the most appropriate silvicultural treatments following the official compendium of best silvicultural practices in the province of Quebec (Laflèche et al. 2013; Thiffault and Hébert 2013; Thiffault et al. 2013). Our financial assessments were made from the Quebec's government perspective, which is funding the white spruce breeding program for the province as well as plantations on public lands. In Quebec as in most other Canadian jurisdictions, tree breeding activities are led by provincial governments, and reforestation programs are mainly taking place on public lands, which represents over $90 \%$ of the Quebec forest territory. The investment decisions are made by the government and their intent is to maximize benefits for the stakeholders directly involved in the activity. As a result, our analysis went beyond the strict consideration of breeding costs and took into account the direct costs and benefits from the plantation activity all the way to harvest, that are generated by either the three following stakeholders: the government, the forest operations and product industries, and the workers (Gregersen and Contreras 1992). The approach followed in the present study thus allowed for comparing the net value of investing in different breeding and deployment scenarios leading to various levels of genetic improvement and various delays in planting improved stocks. The approach is commonly used for decision-making relative to forestry investments made by the Quebec government (for more details, see Gouvernement du Québec 2018; https://www.bmmb.gouv. qc.ca/analyses-economiques/).

For each breeding and deployment scenario analyzed, we estimated the Land Expectation Value (LEV), which is the net present value of an unending series of plantations under the same scenario (Gregory 1987). LEV allows for comparing breeding and deployment scenarios leading to different rotation ages. Scenarios with a positive LEV have greater benefits than costs at a given discount rate and are considered worth realizing. LEV was calculated using the following discrete formula:

$\mathrm{LEV}=\frac{\sum_{t=0}^{r} R_{t}(1+i)^{r-t}-\sum_{t=0}^{r} C_{t}(1+i)^{r-t}}{(1+i)^{r}-1}$ 
where $R_{t}$ is for revenue at year $t, C_{t}$ is for cost at year $t, i$ is discount rate, and $r$ is rotation age (Gregory 1987).

\section{Breeding and deployment scenarios}

Five different breeding and deployment scenarios were tested (Table 1). The first two scenarios (Base and CC) are already implemented as part of the current operations of the white spruce program managed by the Quebec government. The "Base" scenario represents the use of seeds produced from open pollination in second-generation seed orchards already in place. The improved seeds are available in a seed bank and following the current practices; it was assumed that it would take only 2 years to produce the seedlings before the reforestation can take place, which was included in the rotation simulation for this scenario. The scenario with controlled crosses (CC) is the one providing the best genetic gain in volume currently available at an operational scale. The most productive full-sib families were identified after many years of field testing (Gouvernement du Québec 2000), and with this scenario, seeds from recommended controlled crosses are used to mass produce reforestation plants using rooted cuttings. Thus, for this scenario, it was assumed in the rotation simulation that propagules for the reforestation program require a 4-year production period, which includes the time to produce donor plants and then about 10 rooted cuttings from each donor plant. The three other scenarios are hypothetical or at an advanced developmental stage at this point. The $\mathrm{SO} 3$ scenario is hypothetical and corresponds to the third generation of conventional breeding with the establishment of a seed orchard where open-pollinated seed will be collected. We consider that it would take 34 years to complete the third generation of breeding and have access to the seed for the production of seedlings using conventional means, which was included in the rotation simulation. This generation interval is twice that used by Li and Dungey (2018) in their simulations. However, spruces are known to have longer breeding cycles than those of pine species such as Pinus taeda and P. radiata, with the latter being assumed in their simulations. The last two scenarios tested herein are in development at the operational scale and involve genomic selection. They both imply that by virtue of screening a large number of candidates inexpensively with GS, selection intensity can be increased to obtain greater gains while reducing the delays between the selection process and the production of genetically improved reforestation stock to its minimum. The GSTG scenario combines the use of GS to top-grafting in existing first-generation seed orchards, thus combining forward GS and sexual propagation. The aim of this scenario is to combine the advantages of GS and easiness of seed production with open pollination in current seed or breeding orchards. The main advantages are greater flexibility at the selection stage, reduced production delay compared to the establishment of a new seed orchard, and control of production costs. We have estimated that with this scenario, there would be a delay of 8 years before having access to improved seedlings for the reforestation program. Thus, this delay, which was included in the simulated rotation for this scenario, is quite similar to the one used by Li and Dungey (2018) in their simulations, that is 7 years. The last scenario of GSSE tested in the present study combines the use of GS in forward mode with multiclonal propagation (Park et al. 2016), thus using all available sources of genetic variance for selection, leading to the greatest gains among the five scenarios tested. With this scenario, the delay between the selection process and production of genetically improved reforestation stock can also be reduced to its minimum. We have estimated this delay to 4 years only, because the Quebec government has already access to cryopreserved SE lines that were field-tested. This delay was thus included in the simulated rotation for this breeding and deployment scenario.

For the five breeding and deployment scenarios tested, we ran all analyses with an annual level of plantation of 15 million seedlings (Table 1). This equates the historical level of plantation in one of the two white spruce Quebec seed zone (Li et al. 1997), the most meridional one overlying the three sugar maple bioclimatic domains in the province. This was done to facilitate comparisons between scenarios, although for the GSSE scenario, the current production objective is 4 million SE-derived seedlings (S. Carles, Ministère des Forêts, de la Faune et des Parcs du Québec, personal communication).

Table 1 Description of the five breeding and deployment scenarios tested

\begin{tabular}{|c|c|c|c|c|c|}
\hline Abbreviation & Description & $\begin{array}{l}\text { Gain in dominant } \\
\text { height }(\%)\end{array}$ & Type of plants & $\begin{array}{l}\text { Number of years } \\
\text { before plantation }\end{array}$ & $\begin{array}{l}\text { Annual production } \\
\text { (million of plants) }\end{array}$ \\
\hline Base & $\begin{array}{l}\text { Use of open-pollinated seed orchards from } \\
\text { conventional selection (second generation) }\end{array}$ & 8 & Seedlings & 2 & 15 \\
\hline $\mathrm{CC}$ & $\begin{array}{l}\text { Controlled crosses from conventional selection } \\
\text { (second generation) }\end{array}$ & 15 & Cuttings & 4 & 15 \\
\hline $\mathrm{SO} 3$ & $\begin{array}{l}\text { Conventional selection and establishment of } \\
\text { open-pollinated seed orchards (third generation) }\end{array}$ & 16 & Seedlings & 34 & 15 \\
\hline GSTG & $\begin{array}{l}\text { Genomic selection, top-grafting in existing } \\
\text { seed orchards and open pollination }\end{array}$ & 15 & Seedlings & 8 & 15 \\
\hline GSSE & Genomic selection and somatic embryogenesis & 25 & Emblings & 4 & 15 \\
\hline
\end{tabular}




\section{Growth and yield model}

We used an empirical growth and yield model specifically developed for white spruce plantations in Quebec to predict the different characteristics of the plantations at any given age (Prégent et al. 2010). With three parameters (plantation site index (SI), spacing, and age), basal area, stand volume, and average stem diameter at breast height per hectare could be determined using functions of the following forms:

$V=\beta_{0} S I^{\beta_{1}} B A^{\beta_{2}} S p^{\beta_{3}}+e$,

$B A=\beta_{0} S p^{\beta_{1}} S I^{\beta_{2}}\left(1-\exp ^{-\left(\beta_{3}+\beta_{4} S p^{*} A g e\right)}\right)^{\beta_{5}}+e$,

$\bar{D}=\beta_{0} S p^{\beta_{1}} S I^{\beta_{2}\left(1-\beta_{3} \text { age }\right)^{\beta_{4}}}+e$,

where, $V$ is the volume per hectare $\left(\mathrm{m}^{3}\right), \mathrm{BA}$ is the basal area per hectare $\left(\mathrm{m}^{2}\right)$, Sp is the tree spacing at plantation establishment $(\mathrm{m}), \mathrm{SI}$ is the site index which corresponds to the average height of the 100 tallest trees at age $25(\mathrm{~m})$, Age is the age at which we want to estimate the plantation yield, $\bar{D}$ is the average stem diameter at breast height $(\mathrm{cm})$, and $\beta_{1}, \beta_{2}, \beta_{3}, \beta_{4}$, and $\beta_{5}$ are function parameters that are estimated using non-linear regression (Prégent et al. 2010).

Analyses were conducted with a plantation density of 2000 seedlings per hectare on a range of sites whose indices varied from 7 to $14 \mathrm{~m}$ in dominant height at 25 years. The growth and yield tables used do not take into account gains that result from use of genetically improved reforestation stock. While genetic gains are generally estimated as percentage of the average tree height of the reference population, SI corresponds to the average height of the 100 tallest trees per hectare (Prégent et al. 2010). Thus, to use the existing growth and yield tables, expected genetic gains were adjusted and expressed as increases in dominant height (Table 1). To estimate the volume produced by a plantation established with genetically improved stock on a site of a given SI, the later was thus increased by the expected genetic gain, as assumed in previous studies (Talbert et al. 1985; McKeand et al. 2006; Petrinovic et al. 2009). Projected yields for the base and GSES scenarios are presented in Fig. 1. Expected genetic gains presented in Table 1 and used in this study for the various scenarios tested were either estimated from data collected in genetic tests (Petrinovic et al. 2009; Adams et al. 2016) or provided by white spruce breeders as their best estimates based on their extensive experience (A. Rainville, Ministère des Forêts, de la Faune et des Parcs du Québec, personal communication).

\section{Silvicultural treatments}

In order to obtain realistic estimates of financial performance for the five breeding and deployment scenarios tested from breeding to plantation to harvesting, we applied silvicultural treatments that were the most likely to be considered in a context of intensive silviculture in Quebec. The treatments also took into account the current situation with regard to the use of material from progress being made in the Quebec white spruce breeding program as well as associated seed and seedling production objectives for reforestation.

First, we assumed that site preparation would be achieved during the period of seedling production. Thus, plantation could be set up as soon as the seedlings are available. In 2001, the Quebec government banned the use of herbicides on public lands (Thiffault and Roy 2011). The herbicide ban forced a change in silvicultural practices to remove and control competing vegetation. Hence, because the competing vegetation is more aggressive on more fertile sites, the higher the site index, the larger size must be the reforestation seedlings to quickly access the free growth status. Normal-size seedlings (45-110 containers; 45 cavities, $110 \mathrm{~cm}^{3}$ per cavity, minimum height $18 \mathrm{~cm}$ ) are typically used on sites with the lowest site index for white spruce, whereas medium-size (36-200 containers; 36 cavities, $200 \mathrm{~cm}^{3}$ per cavity, minimum height $27 \mathrm{~cm}$ ) and large-size (25-310; 25 cavities, $310 \mathrm{~cm}^{3}$ per cavity, minimum height $35 \mathrm{~cm}$ ) seedlings are used on average and high site index sites, respectively, in order to account for stiffer vegetation competition. Hence, the use of medium- and large-size seedlings results in additional production costs. The number of mechanical cleanings required also depends on the site index. As competing vegetation is more aggressive on most productive sites, it requires a more intensive control for this type of sites. Also, mechanical cleaning is less efficient than herbicide treatment, resulting in the need for more mechanical cleanings on best sites. In the tested scenarios, we thus followed the compendium of best silvicultural practices recommended by the Quebec government (Thiffault et al. 2003; Thiffault and Hébert 2013), and the number of mechanical cleanings ranged from 0 on lower site indices to 3 on higher site indices (Table S1). As a sensitivity analysis, we also tested the impact on LEV of replacing mechanical cleaning by herbicide control of competing vegetation.

In all breeding and deployment scenarios, a commercial thinning was considered when the basal area reached $25 \mathrm{~m}^{2}$ per hectare, following recommendations to maximize the average stem diameter (Laflèche et al. 2013). Treatment age varied between 26 years on best sites for scenarios with the highest genetic gain and 31 years for plantations on poor sites with the lowest genetic gain. We estimated harvested trees and residual stand characteristics with the equation developed by Prégent (2003). Stand age at final harvest was scenariodependent and determined with the maximum net present value following the principle of economic rotation (Binkley 1987; Zhang and Pearse 2012). As an example, expected yields, including commercial thinning and final harvest, are presented in Fig. 2 for two site indices (7 and 14) and for three breeding and deployment scenarios (Base, CC, and GSSE). 
Fig. 1 Projected white spruce plantation yield for a the base scenario, and $\mathbf{b}$ the GSSE scenario, with site productivity indices varying from 7 to $14 \mathrm{~m}$ and with a plantation density of 2000 trees per hectare (see Table 1 for further details on scenarios)
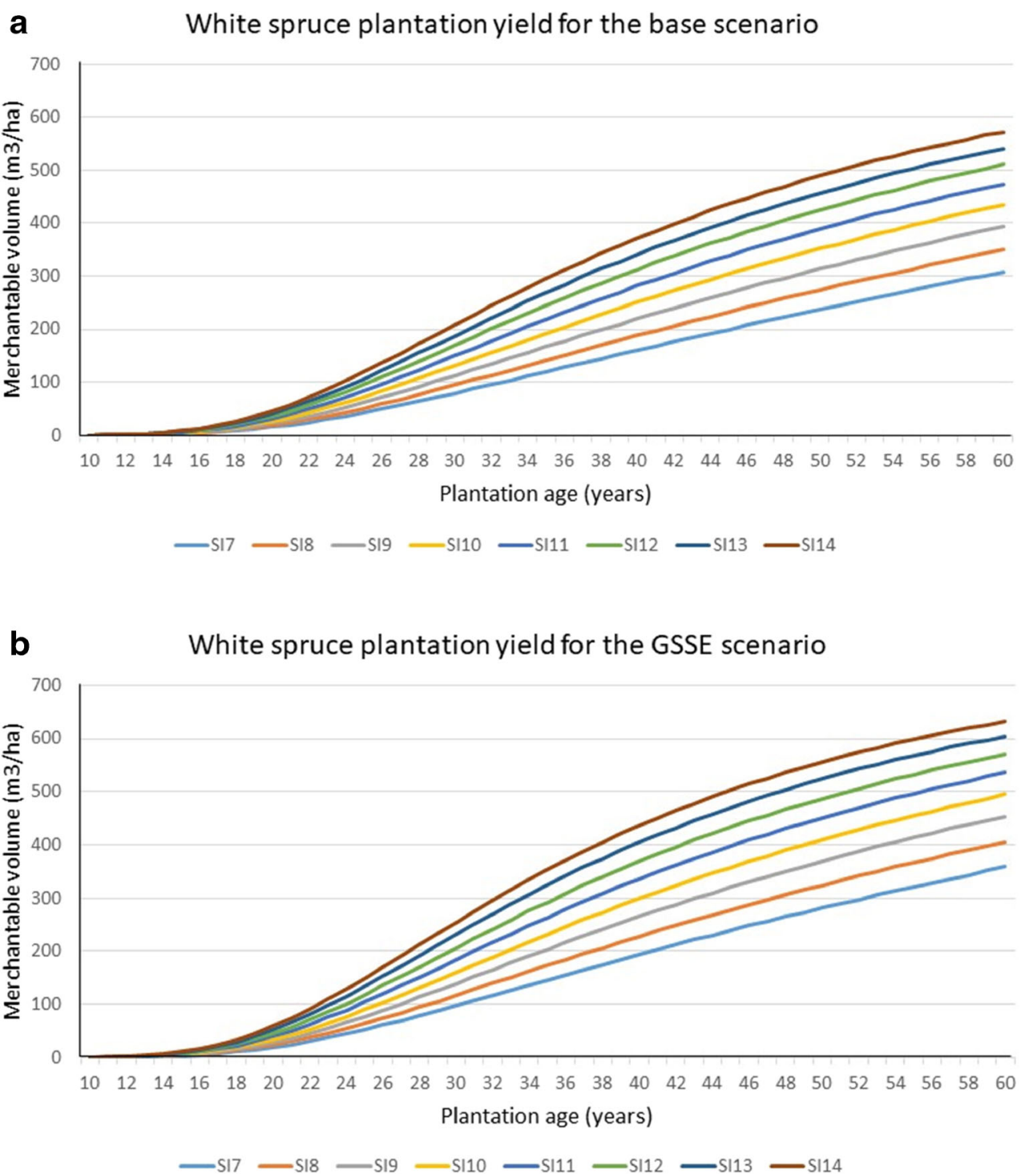

\section{Discount rate}

We used a 4\% discount rate in all financial analyses. This rate was chosen because it is widely used by the Quebec government to assess the economic profitability of investments in silviculture. Also, economic studies in Nordic countries such as Canada usually use discount rates between 2 and 4\% (Jansson et al. 2017). Accordingly, we also tested a $3 \%$ discount rate in sensitivity analyses, as well as a more severe $5 \%$ discount rate.

\section{Benefits}

We considered the benefits generated by the intensively managed plantation activity, and this for the three stakeholders involved, which are the Quebec government, the forest product industry including companies involved with plantation harvest, and the workers. The benefits arise from four sources:
(1) the stumpage value, (2) an adjustment for quality, (3) the corporate profits, and (4) the wage income (Table 2). The data used for our analyses were provided by the Quebec Timber Marketing Board for the year 2016. Stumpage value is a trend value calculated with an econometric model taking into account historic stumpage values, since 1941. It does not consider cyclical fluctuations such as abnormally low or high prices, but it takes into account structural changes in order to obtain a fair income expectancy in the medium and long terms (Gouvernement du Québec 2018). It is expressed in dollars per cubic meter $\left(\$ / \mathrm{m}^{3}\right)$. However, as the use of genetically improved material usually have a significant impact on the quality and productivity of plantations (Mullin et al. 2011), we adjusted the stumpage value using the plantation average stem diameter at breast height (DBH) obtained for each breeding and deployment scenario in order to take into account variations in the lumber recovery factor. The quality 
Fig. 2 Projected white spruce plantation yield, including commercial thinning for a site index 7 and $\mathbf{b}$ site index 14, with three different breeding scenarios: Base (second-generation conventional open-pollinated seed orchard), CC (second-generation controlled crosses), and GSSE (genomic selection with somatic embryogenesis) a White spruce plantation yield with commercial thinning for site index 7

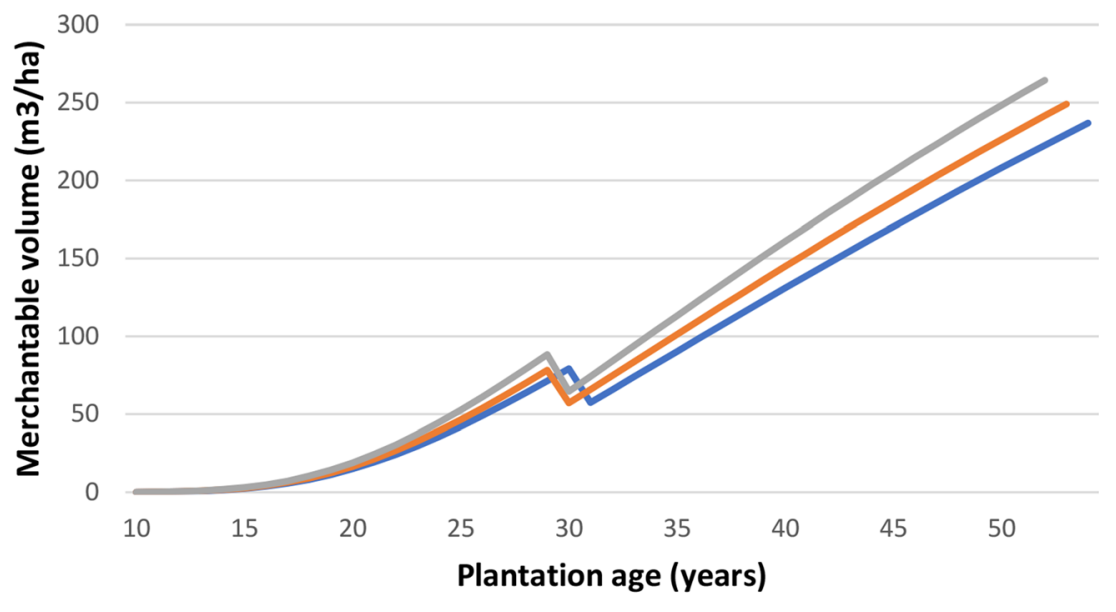

$\longrightarrow$ Base $\longrightarrow$ GSSE

b White spruce plantation yield with commercial thinning for site index 14

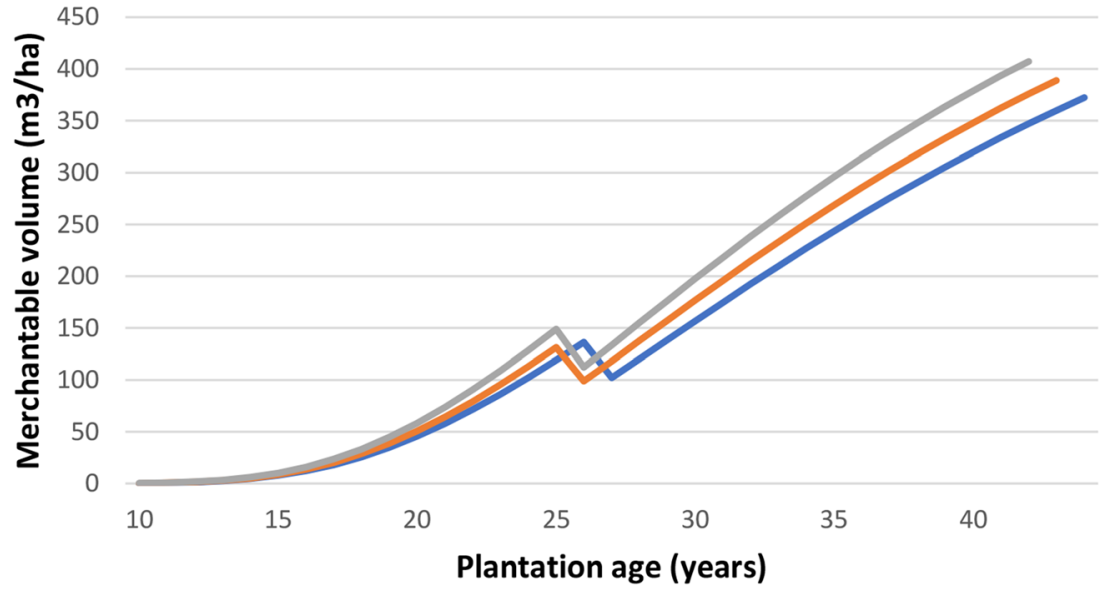

adjustment factor used in our analyses represents the difference between the wood basket value specific to our simulated plantations and the average wood basket value used to establish stumpage value by the Quebec Timber Marketing Board (Fig. 3). The quality adjustment factor ranged from $0.88 \$ / \mathrm{m}^{3}$ for plantations on low site index to $13.90 \$ / \mathrm{m}^{3}$ for plantations on high site index with the best genetic gain.

Corporate profit is the net income before taxes for forestry companies. For commercial silviculture, corporate profit was calculated for the harvesting companies and for the primary and secondary manufacturing industries based on the Annual Survey of Manufacturing and Logging Industries (Statistics Canada 2004-2011) and on the total quantity of round wood harvested. The mean value for the years 2004-2011 was used and adjusted to 2016 based on recorded inflation rates. Wage income is the wealth gap for workers in the forest industry compared to other industries. For commercial silviculture, wage income was also calculated with data from the Annual Survey of Manufacturing and Logging Industries (Statistics Canada 2004-2011) and with the unemployment rate (Gouvernement du Québec 2018).

For non-commercial silviculture activities, we included in our analysis the corporate profits and the wage income for non-commercial forest industries. These are estimated as a percentage of the costs of silvicultural treatments and vary depending on the type of treatment. We considered using dollars per hectare of treatment as a unit $(\$ / \mathrm{ha})$, but value for noncommercial silviculture is considerably variable depending on 
Table 2 Benefit values from commercial and non-commercial silvicultural treatments considered in this study

\begin{tabular}{|c|c|c|c|c|c|}
\hline \multirow[t]{2}{*}{ Benefits } & \multirow[t]{2}{*}{ Sources } & \multirow[t]{2}{*}{ Commercial $\left(\$ / \mathrm{m}^{3}\right)$} & \multicolumn{3}{|c|}{$\begin{array}{l}\text { Non-commercial } \\
\text { ( } \% \text { of silviculture costs) }\end{array}$} \\
\hline & & & Site preparation & Plantation & Competition control \\
\hline Stumpage value & Trend value from historic stumpage values ${ }^{1}$ & 39.09 & - & - & - \\
\hline Quality adjustment & $\begin{array}{l}\text { Plantation wood basket value and average } \\
\text { wood basket value }\end{array}$ & 0.88 to 13.90 & - & - & - \\
\hline Corporate profits & $\begin{array}{l}\text { Annual Survey of Manufacturing and Logging } \\
\text { Industries }{ }^{3} \text { and total quantity of roundwood } \\
\text { harvested }^{4}(2004-2011) \\
\text { Survey on silviculture costs }\end{array}$ & 10.85 & 13.30 & 5.10 & 5.10 \\
\hline Wage income & $\begin{array}{l}\text { Annual Survey of Manufacturing and Logging } \\
\text { Industries } \text { and unemployment rate }^{6} \\
\text { Survey on silviculture costs }{ }^{7}(2007-2008)\end{array}$ & 9.09 & 8.70 & 39.11 & 29.45 \\
\hline
\end{tabular}

${ }^{1}$ Ministère des Forêts, de la Faune et des Parcs du Québec, Internal document

${ }^{2}$ Ministère des Forêts, de la Faune et des Parcs du Québec, Internal document

${ }^{3}$ Statistics Canada (2004-2011)

${ }^{4}$ Ministère des Forêts, de la Faune et des Parcs du Québec, Internal document

${ }^{5}$ Groupe DDM (2016)

${ }^{6}$ ISQ (2014)

${ }^{7}$ Groupe DDM (2009)

the specific intervention modalities. This is why we used a percentage of non-commercial treatment costs to estimate wage income and corporate profits. Corporate profits were estimated from the Survey on silviculture costs (2014-2015) (Groupe DDM 2016), and wage income were estimated from the Survey on silviculture costs (2007-2008) (Groupe DDM

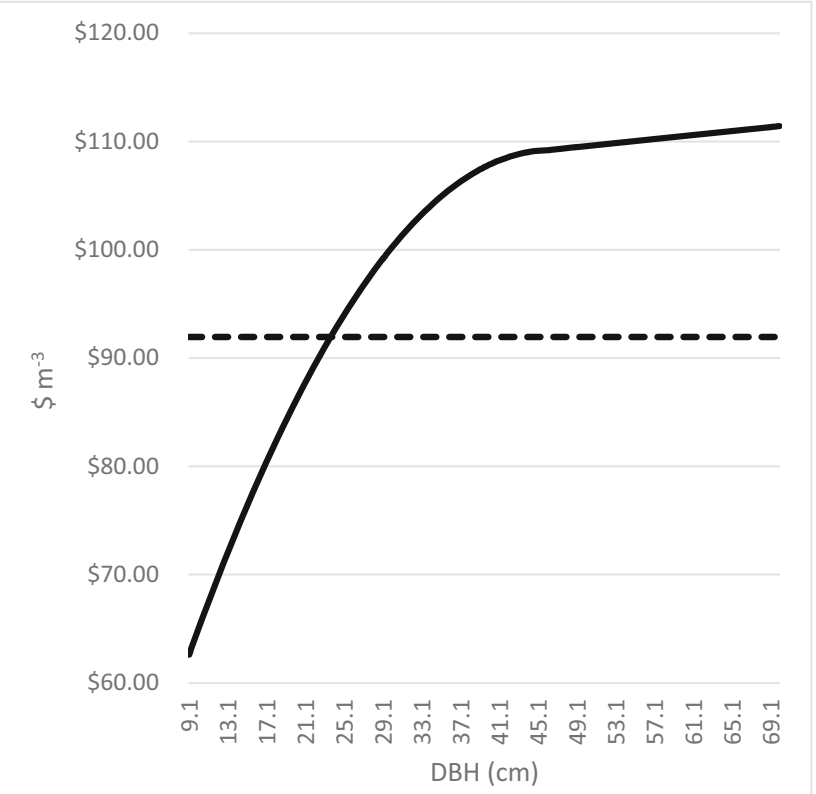

Fig. 3 Wood basket value in relation with mean diameter at breast height (DBH). The dotted line represents the average basket value used to calculate quality adjustments (Source: Internal document, Quebec Timber Marketing Board 2016)
2009). We conducted sensitivity analyses on benefits, by simulating values in a range between -50 and $+50 \%$ of the values used for the main analysis.

\section{Costs}

Each year, according to the Quebec Sustainable Forest Development Act, the Quebec Timber Marketing Board must estimate the costs of silvicultural treatments made on public lands and determine the refund amount that can be claimed by those who have carried out the silvicultural treatments. For our study, we used the price list established for 2016-2017 (Table 3). The costs estimated for the production of seedlings from seeds and SE-derived seedlings were provided by the Seed and Plant Production Branch of the Ministère des Forêts, de la Faune et des Parcs du Québec (MFFPQ). These costs included seed production costs for seedlings and rooted cuttings and costs directly related to SE production for SEderived seedlings. Costs associated with white spruce breeding activities were estimated using past records of the MFFPQ. Based on data collected over the last 30 years, we have estimated that they sum up to $\$ 5$ per hectare of plantation. However, we did not consider these costs for the Base and the CC scenarios because they have already been amortized by the Quebec government. They were included into the costs for the three remaining scenarios to cover either those associated with the next breeding cycle (SO3) or genotyping and data analysis in the scenarios involving genomic selection (GSTG and GSSE). As for benefits, we conducted sensitivity 
Table 3 Costs for silvicultural treatments considered in this study

\begin{tabular}{lll}
\hline Treatments & Seedling size & $\begin{array}{l}\text { Cost per } 1000 \text { seedlings } \\
(\$)\end{array}$ \\
Seedling production & $25-310$ & 590 \\
& $36-200$ & 329 \\
& $45-110$ & 194 \\
& $25-310$ (Cuttings) & 1021 \\
& $36-200$ (Cuttings) & $558^{*}$ \\
& $45-110$ (Cuttings) & $319^{*}$ \\
& $25-310$ (Emblings) & 1147 \\
& $36-200$ (Emblings) & $684^{*}$ \\
Plantation & $45-110$ (Emblings) & $445^{*}$ \\
& $25-310$ & 475 \\
Treatments & $36-200$ & 400 \\
Site preparation & - & 305 \\
Mechanical cleaning & - & $\$$ ha \\
Commercial thinning & - & 500 \\
Harvesting & & 1200 \\
\hline
\end{tabular}

*Estimated values

$\dagger$ Source: FPInnovations (2015)

analyses on costs by simulating values in a range between -50 and $+50 \%$ of the values used for the main analysis.

\section{Results}

The results of the financial analyses for the five breeding and deployment scenarios tested are presented in Fig. 4 and Table S2. Total costs, age of final harvesting, and volumes harvested at both thinning and final harvest are presented in Table S3. LEVs were positive for all scenarios and varied from around $\$ 200$ to $\$ 2000$ per hectare, depending of the scenario tested and the site index. Generally, values increased with site index. The GSSE scenario generated the highest profits whatever the site index. The SO3 scenario produced the lowest LEV. Our results indicate that an increase in site index means an increase in LEV. However, there was a peak for every breeding and deployment scenarios on site index 8 , followed by a drop in LEV on site index 9. Then, LEV progressively increased to reach the highest values on site index 14. For Base and CC scenarios, LEV at site index 8 was only outweighed by LEV at site index 14. For the SO3, GSTG, and GSSE scenarios, LEV at site index 8 was outweighed by LEV from site indices 12 and higher. The drop in LEV at site index 9 and the slow recovery on higher site indices can be explained by the fact that no mechanical control of the

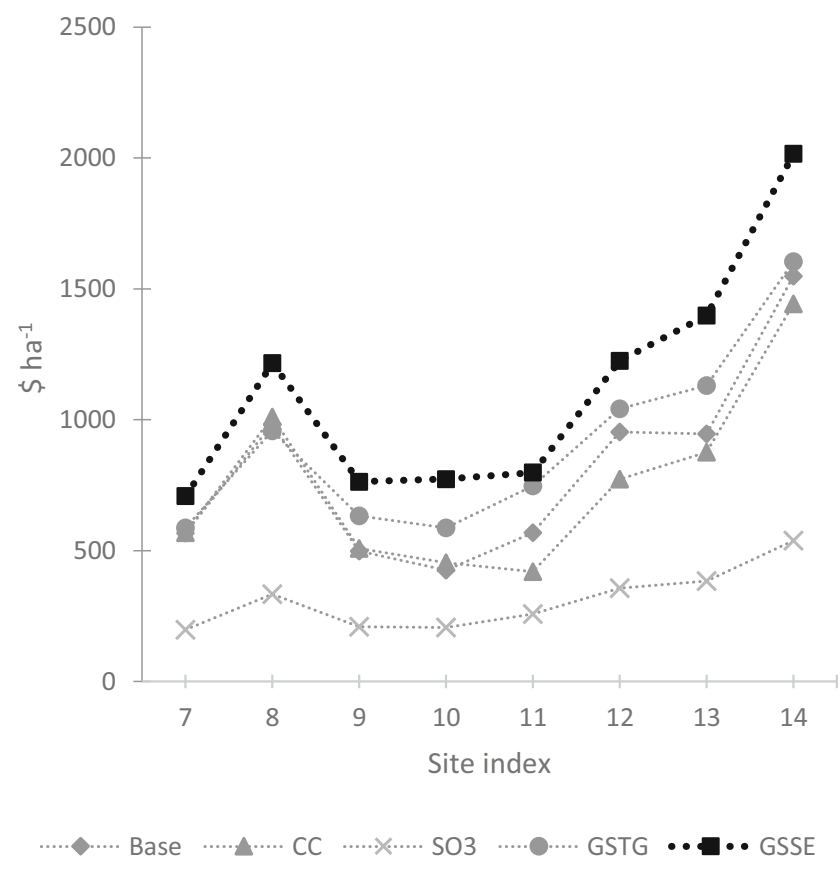

Fig. 4 Land expectation values (LEVs) for the five breeding and deployment scenarios tested as a function of site index with a $4 \%$ discount rate (abbreviations used for scenarios: Base, second-generation conventional open-pollinated seed orchard; CC, second-generation controlled crosses; SO3, third generation of conventional breeding with seed orchard; GSTG, genomic selection with top-grafting; GSSE, genomic selection with somatic embryogenesis; see Table 1 for further details on scenarios tested)

competing vegetation is required on low-productivity sites (site index lower than 9). Moreover, as silviculture costs increased significantly with site index (Table S1), it affected negatively the progression in LEV with site index.

\section{Sensitivity analyses}

\section{Discount rate}

We performed sensitivity analyses to assess the impact of a lower discount rate on LEV. Using a $3 \%$ discount rate instead of $4 \%$, LEV increased for all breeding and deployment scenarios and site indices (Fig. 5, Table S4). The GSSE scenario still resulted in the highest LEVs for every site index, and the SO3 scenario in the lowest values.

At $5 \%$ discount rate, there was a significant shift in LEV (Fig. 6, Table S5). Most of the LEVs turned negative, except for the majority of the scenarios on lowest productivity sites, and for few breeding and deployment scenarios on the most productive sites. The CC scenario produced the lowest LEV. The GSSE scenario produced the highest profit on site index 8. GSTG and GSSE scenarios also produced profits on sites with the highest site indices, although profits were less high. 


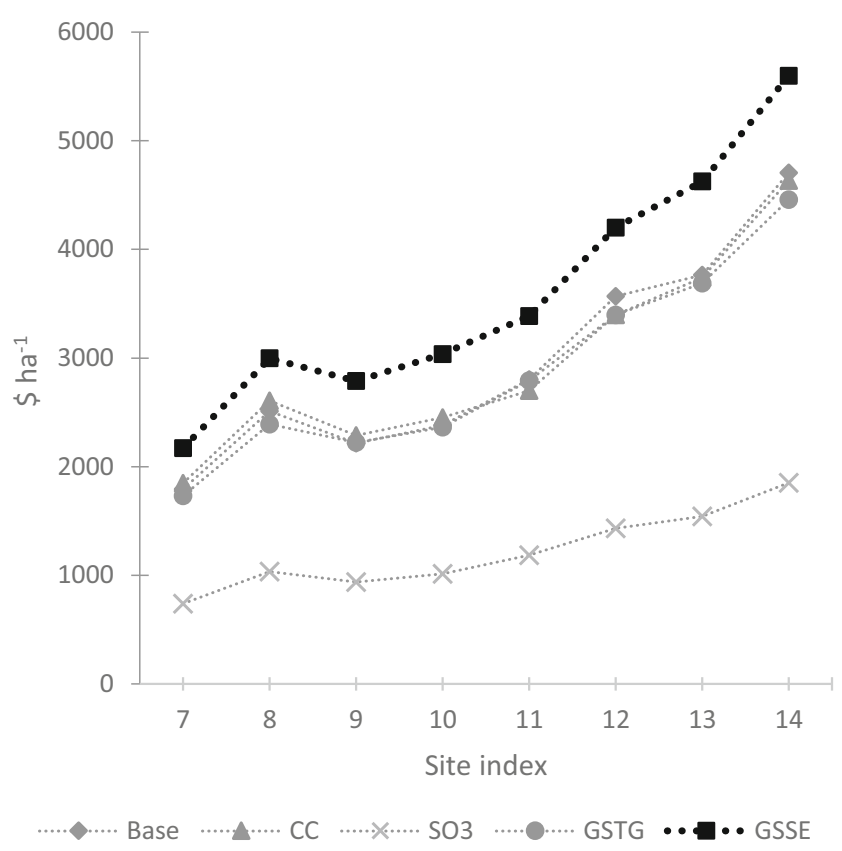

Fig. 5 Land expectation values (LEVs) for the five breeding and deployment scenarios tested as a function of site index with a $3 \%$ discount rate. (abbreviations used for scenarios: Base, second-generation conventional open-pollinated seed orchard; CC, second-generation controlled crosses; $\mathrm{SO} 3$, third generation of conventional breeding with seed orchard; GSTG, genomic selection with top-grafting; GSSE, genomic selection with somatic embryogenesis; see Table 1 for further details on scenarios tested)

\section{Costs and benefits}

We performed sensitivity analyses on the values of costs and benefits to assess the impact of variation in costs and benefits on LEV. Hence, total benefits (B), total costs (C), stumpage value (S), wage income (WI), and corporate profits $(\mathrm{CP})$ were increased or decreased by up to $50 \%$. These sensitivity analyses were conducted for the GSSE scenario for site index 10 (Fig. S1), site index 12 (Fig. S2), and site index 14 (Fig. 7), with a $4 \%$ discount rate, given that this was the most profitable scenario estimated with average costs and benefits values.

Among all the three sources of benefits considered in the analyses, the stumpage value had the greatest impact on LEV, closely followed by wage income. A reduction of $50 \%$ of the stumpage value or wage income resulted in a negative LEV for site index 10 and 12. Corporate profits had the lowest impact on LEV, and even a reduction of $50 \%$ did not result in negative LEV. A reduction of $25 \%$ in total benefits lead to negative LEV for the three site indices tested. An increase in silviculture costs can also impact significantly LEV. Hence, a $25 \%$ increase was tested and resulted in negative LEV for site index 10; a $50 \%$ increase resulted in negative LEV for site indices 10, 12, and 14.

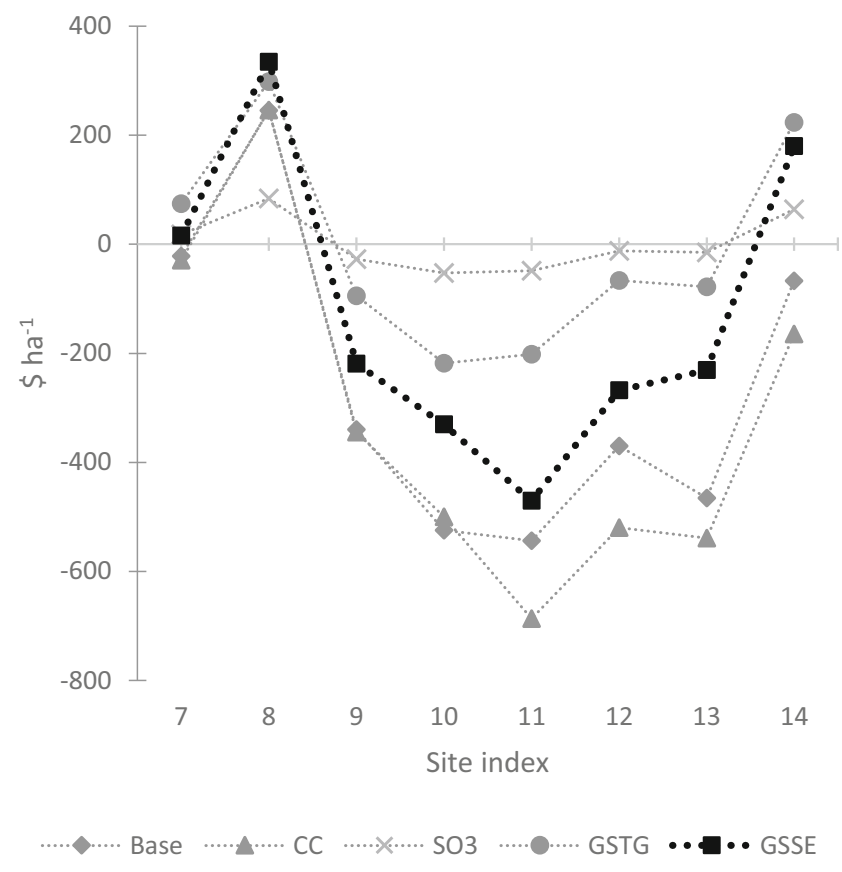

Fig. 6 Land expectation values (LEVs) for the five breeding and deployment scenarios tested as a function of site index with a $5 \%$ discount rate (abbreviations used for scenarios: Base, second-generation conventional open-pollinated seed orchard; CC, second-generation controlled crosses; SO3, third generation of conventional breeding with seed orchard; GSTG, genomic selection with top-grafting; GSSE, genomic selection with somatic embryogenesis; see Table 1 for further details on scenarios tested)

\section{Herbicide treatments}

Considering that Quebec is the only provincial jurisdiction in Canada where the use of herbicide to control competing vegetation on public land is banned, we wanted to assess the impact on LEV of replacing mechanical cleaning by herbicide control for the five breeding and deployment scenarios tested. This sensitivity analysis is hypothetical in the Quebec's context considering the herbicide ban in place, but such analysis could be of value for practitioners from other jurisdictions. To do so, we had to make some changes to the silvicultural treatments in the simulation models, because there is no need for the use of more costly medium- or large-size seedlings under herbicide treatment. Thus, normal-size seedlings were used on every site index for the simulations assuming herbicide control (Table S1). Consequently, on sites with average or high site index, plant production and plantation costs were significantly reduced compared with equivalent scenarios using mechanical cleaning. Also, herbicides are known to be more efficient than mechanical clearing at controlling competing vegetation (Thompson and Pitt 2003) and, as a rule of thumb, the number of herbicide sprayings was set to be lower than the number of mechanical cleaning operations on sites of similar index (Table S1) (N. Thiffault, Canadian Forest Service, personal communication). We estimated the cost of herbicide treatment on public lands at 


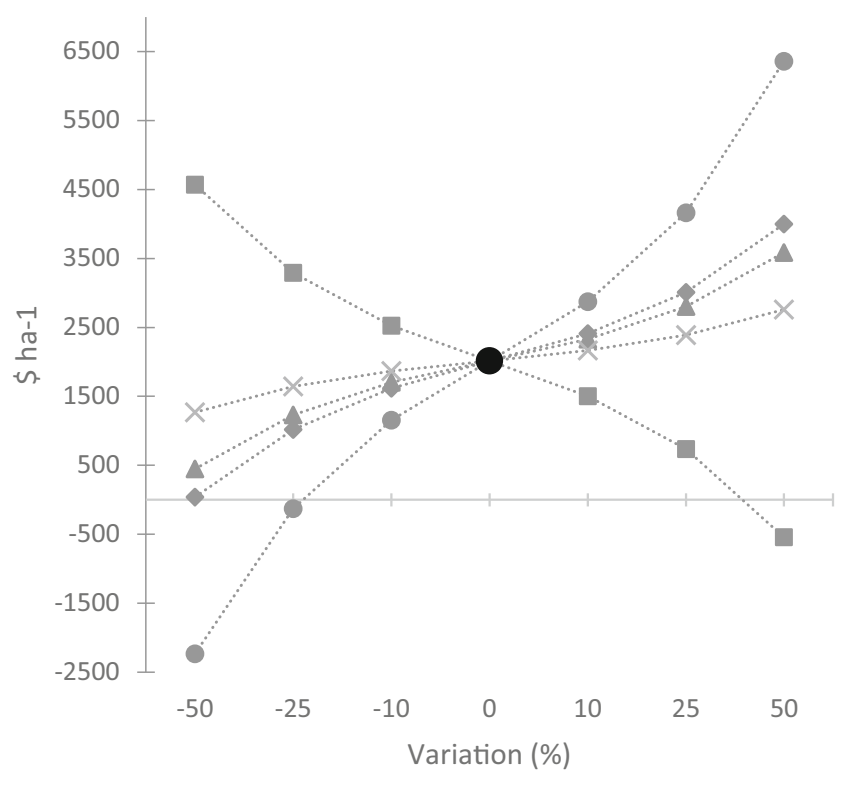

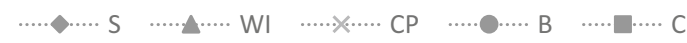

Fig. 7 Sensitivity analyses of land expectation values (LEVs) for the scenario of genomic selection with somatic embryogenesis on site index 14 at $4 \%$ discount rate (abbreviations used for sensitivity analyses: S, stumpage value; WI, wage income; $\mathrm{CP}$, corporate profits; $\mathrm{B}$, total benefits; C, total costs)

\$200/ha, based on data obtained from the New Brunswick province and from private landowners in Quebec (M. Noël, New Brunswick Department of Energy and Resource Development, personal communication).

The LEV results for simulations assuming control of competing vegetation with herbicide treatment are presented in Fig. 8 and Table S6. The values obtained were at least twice higher than those of the equivalent simulations but with mechanical cleaning of competing vegetation. GSSE was the most profitable scenario in simulations assuming herbicide treatment, with highest LEV on every site index. The SO3 scenario had the lowest LEV on every site index. LEV increased with site index for every breeding and deployment scenario tested.

\section{Discussion}

Results of the present financial analyses show positive LEV for all breeding and deployment scenarios, including silvicultural treatments, tested on all site indices at a $4 \%$ discount rate. Thus, white spruce plantations in the area covered by the study generate benefits even with the scenario assuming the lowest genetic gain. Ahtikoski et al. (2018) found that plantation with improved reforestation stocks can have benefits for both the tree growers and sawmill operators, although it depends on the financial data and assumptions used (see for instance, Chang et al. 2019). The scenario of using genomic selection combined with SE-derived plants (GSSE) had the highest genetic

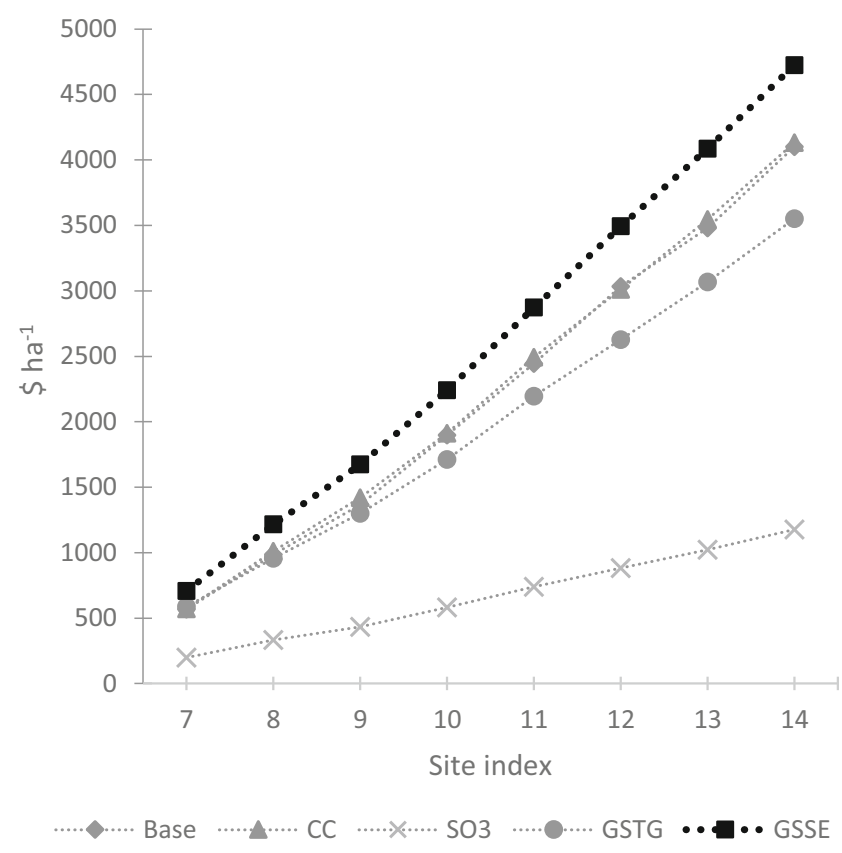

Fig. 8 Sensitivity analyses of land expectation values (LEVs) with herbicide control of competing vegetation at $4 \%$ discount rate (abbreviations used for scenarios: Base, second-generation conventional open-pollinated seed orchard; CC, second-generation controlled crosses; SO3, third generation of conventional breeding with seed orchard; GSTG, genomic selection with top-grafting; GSSE, genomic selection with somatic embryogenesis; see Table 1 for further details on scenarios tested)

gain and achieved the highest LEV, even though production costs for SE-derived seedlings were higher than those of seedlings from seeds, as assumed for the four other breeding and deployment scenarios. The additional investment appears justified by the increase in volume, as reported in previous studies for other species (McKeand et al. 2006; Ahtikoski et al. 2013), but also by shortening the breeding cycle (Beaulieu et al. 2014b). Moreover, in the future, we should expect higher benefits arising from a reduction in the costs of SE-derived plants produced at a larger scale. In 2011, MFFPQ set up a world-class SE facility that would indeed allow increasing by several fold the number of SE-derived seedlings yearly produced (Tremblay and Lamhamedi 2006; Ministère des Ressources naturelles et de la Faune du Québec 2011). The use of robot technology could also help reduce the costs of seedlings produced by somatic embryogenesis (Find and Krogstrup 2008). However, when we tested the GSSE scenario with a reduced yearly production of 4 million SE-derived plants instead of 15 million plants, the LEV obtained for any site index was only marginally reduced (data not shown). Thus, it appears that even without a scale economy, the GSSE scenario would stay highly profitable at the hectare scale, and at the provincial scale, use of robotics could generate more net benefits.

The scenario combining genomic selection with topgrafting in existing seed orchards (GSTG) also showed 
interesting results, with the second best LEV on every site index in our main analysis. The results suggest that this scenario could be an interesting alternative to increase genetic gain and shorten breeding cycles for tree breeding programs where somatic embryogenesis at an operational scale is not available, as shown by Li and Dungey (2018). However, this scenario remains in development for white spruce, as it remains to be tested thoroughly at the seed orchard scale in real field conditions. But it indicates that genomic selection is profitable even without access to somatic embryogenesis to produce reforestation stock, thus confirming similar findings in British Columbia (McWilliams 2015). Furthermore, it should make it possible to amortize investment on a much larger number of hectares compared to multiclonal forestry. However, the impact of various deployment strategies of genetically improved reforestation stock on the amortization of GS investment in tree breeding programs has yet to be estimated for most species.

When we applied a strict financial analysis to our various breeding and deployment scenarios with the sole revenue originating from the stumpage value, without considering the benefits for the other stakeholders directly involved in the plantation activities, i.e., by excluding forest workers and forest products companies, we obtained negative net present values (not shown) similarly to Chang et al. (2019). However, when a government, such as the Quebec government, invests in plantations on public lands, it is not only concerned with negative and positive cash flows related to this activity. Indeed, the activity generates direct benefits for other stakeholders in the society. This is why the present analytical approach also took into account the opportunity cost of the factors of production (infrastructure and labor) and considered that broader financial analysis is more appropriate than a strict financial analysis because the plantation activity must seek to create the maximum of well-being and wealth from a government's perspective, under a context of limited financial, human, and physical resources (e.g., industrial infrastructure, equipment, machinery) (Gouvernement du Quebec 2018).

Generally, we observed an increase in LEV with site index, suggesting that the best genetic material should be used on best sites, as indicated in previous studies (McKeand et al. 2006; Petrinovic et al. 2009; Chang et al. 2019). However, we were expecting a more linear growth trend in LEV, proportional to the increase in site index. On the contrary, plantations on lower site indices had superior LEV compared to plantations on average quality sites, and only the plantations on the best sites had LEV superior to that of low-quality sites. In another study conducted by the Quebec government, it was found that the large effort required for cleaning competing vegetation, which is necessary on best sites, represents a barrier to financial performance (Labbé et al. 2014). This conclusion is specific to silvicultural scenarios that rely on mechanical cleaning of competing vegetation, considering the increased costs that must be considered in the analysis. For example, large-size seedlings used on best sites are three times more expensive to produce than standard seedlings, and mechanical control of competing vegetation is six times more expensive than herbicide treatments. Previous studies found that herbicide treatments are three times more cost-effective than mechanical cleaning of competing vegetation (Dampier et al. 2006) and that the LEV of a plantation regime with herbicide treatment nearly doubled that of plantations without it (Van Deusen et al. 2010). Thus, the much reduced financial performance of white spruce plantations on average sites is likely specific to the province of Quebec where the use of herbicide is banned and replaced by mechanical cleanings. Indeed, mechanical cleanings are not applied on low-quality sites where competing vegetation is a lesser problem, whereas they must be applied on sites with average and best productivity. Moreover, larger seedlings are required on sites with average and best productivity to counteract the negative effects of more competing vegetation. In our simulation on average sites, gains in volume did not counterbalance the negative effects of increased mechanical cleaning costs on the financial performance of plantations, whereas gains in volume on best sites were sufficient to obtain financial performance that was higher than that of low-productivity sites while covering higher costs related to multiple mechanical cleanings. Stand-level optimization was not realized in this study, which can explain the counter-intuitive results we obtained on average sites. Strict plantation and thinning instructions were modelized, according to the compendium of best silvicultural practices in Quebec (Thiffault and Hébert 2013) with the objective in mind to maintain monospecific stands free of competing vegetation. Stand-level optimization, considering a more extensive approach, would have probably led to different results, with the possibility to increase LEV on average sites (Tahvonen et al. 2013; Pukkala et al. 2014).

The impact of discount rate on the estimations of LEV was assessed through sensitivity analyses. Our baseline analysis was carried at a $4 \%$ discount rate, which corresponds to the standard used by the Quebec government in its own economic and financial analyses. In doing so, financial performance of the scenarios tested in the present study would be more directly comparable with that of other investment options for the Quebec government. The results obtained were positive for every breeding and deployment scenario tested and for every site index with silvicultural options considered. However, with a discount rate increased to $5 \%$, an important shift in LEV was observed, with negative values obtained for most breeding and deployment scenarios. Higher discount rates also had strong negative impacts on the results of the financial analysis made by Chang et al. (2019) in Alberta. Changes in discount rate are known to have significant impacts on the economic rotation length (Leech 2014). An increase in discount rate translates in a decrease in economic 
rotation length, and thus in final volume harvested. Shorter rotation length may also have a negative impact on the wood properties of harvested trees (Duchesne 2006). Considering that spruces are mainly produced for lumber and that mechanical properties are important for this specific end-product (Zhang and Koubaa 2008), we also felt compelled to test a lower 3\% discount rate, which resulted in highly profitable outcomes for all scenarios. Use of a $3 \%$ discount rate also appears reasonable, considering that economic analyses in Nordic countries generally rely on lower discount rates in the range of 2 to $4 \%$; rarely, rates exceeding $4 \%$ are considered (Jansson et al. 2017).

Beyond certain thresholds, variation in costs and benefits can impact significantly LEV (Anderson and Luckert 2007). In the present study, a $25 \%$ reduction of the total benefits lead to negative LEVs, even for the best breeding and deployment scenario tested. Considering that wage income and corporate profits are average sectorial data that do not take into consideration the specific context of intensive plantation forestry, sensitivity analyses were conducted to assess their impacts on LEV. Variation in wage income impacted more significantly LEV, leading to negative LEVs with a reduction of up $50 \%$. Variation in corporate profits had a lesser significant impact: even with a 50\% reduction, LEVs were positive for the three site indices tested. Variation in stumpage value contributed the most to variation in LEV, compared to the other benefits included in our analyses. Fluctuation in stumpage value are common place, considering that stumpage values are adjusted with the evolution of wood product markets. As we worked with historical data that take into account market fluctuations, our results would be optimistic in a downturn context and pessimistic in favorable market conditions. However, over the long term, our results nevertheless provide a fair expectancy of LEV. Our sensitivity analyses also highlighted the importance of cost control to ensure profitable investments.

Sensitivity analyses also showed that the herbicide ban on Quebec public lands comes with a significant opportunity cost, as previously found in other jurisdictions (Van Deusen et al. 2010). LEVs were at least twice higher when competing vegetation was assumed to be controlled with herbicide treatments rather than by mechanical cleaning. Homagain et al. (2011) also reached the conclusion that aerial herbicide is the most cost-effective way to suppress competition, while mechanical control of competing vegetation could still be profitable. The use of herbicide treatments is also controversial in other provinces of Canada, like in Ontario and New Brunswick, where social acceptability appears to be low (Wyatt et al. 2011). However, our study indicates that it is possible to generate benefits for the society with intensive plantation forestry even by relying on more costly mechanical cleaning of competing vegetation instead of herbicide treatments.
Some cost-mitigation strategies could be explored and tested in the field for specific breeding and deployment scenarios in order to further improve financial performance. For instance, in the case of the GSSE scenario where production of SE-derived seedlings is expensive, reforestation with a combination of seedlings produced from seeds and SEderived seedlings might likely result in reduced plantation costs, without sacrificing yield and financial performance (Lelu-Walter et al. 2013). Assuming that SE-derived trees would outperform the less improved trees from seedlings that would be harvested at commercial thinning, the final harvest should be similar to that of a plantation established entirely with more expensive SE-derived material. Park (2002) suggested a ratio of $60 \%$ of SE-derived plants and $40 \%$ of seedlings from low-cost seed orchard seeds. In our analysis, it would result in a reduction in plant production costs ranging from $200 \$ \mathrm{ha}^{-1}$ to $450 \$ \mathrm{ha}^{-1}$, thus further improving financial performance from using the GSSE scenario. Also, the faster growth rate obtained at the juvenile stage from SE-derived seedlings with highest genetic improvement might reduce the need to control competing vegetation. On the best sites, three mechanical controls are recommended to assure free growth in the compendium of best silvilcultural practices in Quebec (Thiffault and Hébert 2013), but the possibility to reduce the number of mechanical cleaning treatments with such fast-growing seedlings would further increase the LEV for the GSSE scenario by a significant amount.

\section{Limits and perspectives}

There are some limitations to the methodology used. We did not perform full economic analyses, which means that not all costs and benefits were taken into account. As our focus was on the timber values of plantations obtained from various breeding and deployment scenarios, only the costs and benefits directly related to the wood produced were considered. Non-timber values, indirect use value, and non-use value were not considered in our analysis because the effect of silvicultural investment on other uses and services is little known, given the intangible and sometimes subjective nature of most of them. Our intent was thus to carry out comparative financial analyses following the methodology used by the Quebec government for analyzing investments in silviculture, including tree breeding programs and genomic selection more specifically. Next possible steps would be to include amenity values for carbon sequestration, biodiversity, and landscape values (Sedjo 2002). Also, our current analyses were based on the present technological context in the Canadian and Quebec forestry sectors. Widespread use of mechanization is anticipated in the future for seedling production, tree planting, and vegetation competition control, which could impact significantly LEV. 
For spruces in general and white spruce in particular, breeding programs have mainly focused on improving growth and stem straightness in the past (Mullin et al. 2011). The analyses presented here reflect this reality and only takes into account the genetic gains in volume. However, recent work has started to focus on the improvement of wood properties, among others (Lenz et al. 2013; Desponts et al. 2017), and genomic selection models are being developed on Canadian spruces for these traits as well (Beaulieu et al. 2014a, 2014b; Lenz et al. 2017). Wood density and volume are generally negatively correlated, suggesting that breeding programs focusing only on growth rate could have a negative impact on wood quality if attention is not being paid to identify trees that are correlation breakers (Park et al. 2012). Thus, any further financial performance analysis should consider both growth rate and wood properties to assess any trade-off between these two classes of traits and how multi-trait selection schemes could be developed and implemented (Lenz et al. 2019). Regarding this challenge, one interesting aspect of genomic selection compared to conventional selection approaches is that it can allow screening very large numbers of candidates (thousands) for wood quality traits without phenotyping them at the mature stage (Lenz et al. 2017), so to identify at an early stage correlation breakers with both high growth and adequate wood quality for use as reforestation stock. Contrary to common beliefs, cost of genomic selection, including genotyping costs, are small ( $\$ 5 / \mathrm{ha})$ compared to the other costs involved in a plantation program. Also, better pest resistance and resilience to climatic extremes such as drought episodes should also be integrated into economic analysis, in order to help breeders selecting the best genotypes with appropriate economic weights for each trait (Aubry et al. 1998; Ivković et al. 2006; Berlin et al. 2012; Lenz et al. 2019). The impacts of climate change on tree growth under diverse scenarios should be considered to demonstrate how genomic selection could help mitigate their effects. Such tree breeding and costbenefit investigations were initiated recently under the Canadian Spruce-Up advanced genomics project (www. spruce-up.ca).

Acknowledgements We thank Sylvie Carles (seeds and seedlings production branch of MFFPQ) who provided insights which greatly supported the research, for providing feedback on a previous version of this manuscript and for sharing seedlings production costs. We thank Mélissa Lainesse (Quebec Timber Marketing Board) for sharing economic data. We are grateful to Nelson Thiffault (Canadian Forest Service) and Charles Ward (Research Branch of MFFPQ) for their insights on best silviculture practices. We also thank Guy Smith (Canadian Wood Fibre Centre) for his role in the early coordination of the project, and Patrick Lenz (Canadian Wood Fibre Centre) for sharing ideas about trends in genomic selection and wood quality research. We also acknowledge the insightful suggestions made by reviewers on a previous version of this manuscript. Finally, we would like to extend our gratitude to our colleagues and partners in the FastTRAC spruce genomics project for their precious comments and insights during the course of this research.
This research was part of the FastTRAC and Spruce-Up large-scale genomic projects. FastTRAC is led by J. Bousquet and G. Smith, and is funded by Genome Canada and Genome Québec through the Genomic Applications Partnership Program (GAPP). The project is also supported by contributions from the Ministère des Forêts, de la Faune et des Parcs du Québec, FPInnovations, J.D. Irving Ltd., the New Brunswick Tree Improvement Council, and the Canadian Wood Fibre Centre of Natural Resources Canada. Spruce-Up is led by J. Bohlmann and J. Bousquet, and funded by Genome Canada, Genome BC, Génome Québec, and Genome Alberta through the Large-Scale Applied Research Project Program (LSARP).

\section{Compliance with ethical standards}

Conflict of interest The authors declare that they have no conflict of interest.

Data archiving statement Data have been stored in our institutions' databases. It can be shared upon request to the corresponding author according to the intellectual property policies (IPP) of participating governmental institutions. Therefore, data have not been deposited directly into a public domain.

Open Access This article is licensed under a Creative Commons Attribution 4.0 International License, which permits use, sharing, adaptation, distribution and reproduction in any medium or format, as long as you give appropriate credit to the original author(s) and the source, provide a link to the Creative Commons licence, and indicate if changes were made. The images or other third party material in this article are included in the article's Creative Commons licence, unless indicated otherwise in a credit line to the material. If material is not included in the article's Creative Commons licence and your intended use is not permitted by statutory regulation or exceeds the permitted use, you will need to obtain permission directly from the copyright holder. To view a copy of this licence, visit http://creativecommons.org/licenses/by/4.0/.

\section{References}

Adams GW, Kunze HA, McCartney A, Park Y-S (2016) An industrial perspective on the use of advanced reforestation stock technologies. In: Park Y-S, Bonga JM, Moon H-K (eds) Vegetative propagation of Forest trees. National Institute of Forest Science, Seoul, pp 323-334

Ahtikoski A, Ojansuu R, Haapanen M, Hynynen J, Kärkkäinen K (2012) Financial performance of using genetically improved regeneration material of scots pine (Pinus sylvestris L.) in Finland. New For 43: 335-348. https://doi.org/10.1007/s11056-011-9284-6

Ahtikoski A, Salminen H, Ojansuu R, Hynynen J, Kärkkäinen K, Haapanen M (2013) Optimizing stand management involving the effect of genetic gain: preliminary results for Scots pine in Finland. Can J For Res 43:299-305. https://doi.org/10.1139/cjfr-2012-0393

Ahtikoski A, Haapanen M, Hynynen J, Karhu J, Kärkkäinen K (2018) Genetically improved reforestation stock provides simultaneous benefits for growers and a sawmill, a case study in Finland. Scand J For Res 33:484-492. https://doi.org/10.1080/02827581.2018. 1433229

Anderson J, Luckert M (2007) Can hybrid poplar save industrial forestry in Canada?: A financial analysis in Alberta and policy considerations. For Chron 83:92-104. https://doi.org/10.5558/tfc83092-1

Aubry CA, Adams WT, Fahey TD (1998) Determination of relative economic weights for multitrait selection in coastal Douglas-fir. Can J For Res 28:1164-1170. https://doi.org/10.1139/x98-084 
Beaulieu J (1996) Breeding program and strategy for white spruce in Quebec. Natural Resources Canada, Canadian Forest Service Quebec. Inf rep LAU-X-177E. 23 p

Beaulieu J, Doerksen T, Clément S, Mackay J, Bousquet J (2014a) Accuracy of genomic selection models in a large population of open-pollinated families in white spruce. Heredity 113:343-352. https://doi.org/10.1038/hdy.2014.36

Beaulieu J, Doerksen TK, MacKay J, Rainville A, Bousquet J (2014b) Genomic selection accuracies within and between environments and small breeding groups in white spruce. BMC Genomics 15:1048, 14 p. https://doi.org/10.1186/1471-2164-15-1048

Berlin M, Jansson G, Lönnstedt L, Danell Ö, Ericsson T (2012) Development of economic forest tree breeding objectives: review of existing methodology and discussion of its application in Swedish conditions. Scand J For Res 27:681-691. https://doi.org/ 10.1080/02827581.2012.672586

Binkley CS (1987) When is the optimal economic rotation longer than the rotation of maximum sustained yield? J. Environ Econ Manage 14: 152-158. https://doi.org/10.1016/0095-0696(87)90013-1

Bonga JM (2016) Conifer clonal propagation of forest trees. In: Park Y-S, Bonga JM, Moon H-K (eds) Vegetative propagation of Forest trees. National Institute of Forest Science, Seoul, pp. 3-31

Cervelli R, Senaratna T (1995) Economic aspects of somatic embryogenesis. In automation and environmental control in plant tissue culture. Aitken-Christie, J. Kozai, T., Smith, M.A.L., eds. Kluwer Academic Publishers. pp. 29-64

Chang W-Y, Gaston C, Cool J, Thomas BR (2019) A financial analysis of using improved planting stock of white spruce and lodgepole pine in Alberta: genomic selection versus traditional breeding. Forestry 92: 297-310. https://doi.org/10.1093/forestry/cpz011

Chen ZQ, Baison J, Pan J, Karlsson B, Andersson B, Westin J, Garcia-Gil MR, Wu HX (2018) Accuracy of genomic selection for growth and wook quality traits in two control-pollinated progeny trials using exome capture as the genotyping platform in Norway spruce. BMC Genomics 19:946, 16 p. https://doi.org/10.1186/s12864018-5256-7

Corriveau A, Beaulieu J, Daoust G (1991) Heritability and genetic correlations of wood characters of Upper Ottawa Valley white spruce populations grown in Quebec. For Chron 67:698-705

Dampier JEE, Bell FW, St-Amour M, Pitt DG, Luckai NJ (2006) Cutting versus herbicides: tenth-year volume and release cost-effectiveness of sub-boreal conifer plantations. For Chron 82:521-528. https:// doi.org/10.5558/tfc $82521-4$

Desponts M, Perron M, DeBlois J (2017) Rapid assessment of wood traits for large-scale breeding selection in Picea mariana [Mill.] B.S.P. Ann For Sci 74:1-12. https://doi.org/10.1007/s13595-017-0646-x

Duchesne I (2006) Effect of rotation age on lumber grade yield, bending strength and stiffness in jack pine (Pinus banksiana Lamb.) natural stands. Wood Fiber Sci 38:84-94

Find J, Krogstrup P (2008) Integration of biotechnology, robot technology and visualisation technology for development of methods for automated mass production of elite trees. Work Pap Finnish For Res Inst 114:72-77

FPInnovations (2015) Mise à jour des équations de productivité de la récolte. Rapport présenté au Ministère des Forêts, de la Faune et des Parcs, Gouvernement du Québec, Québec

Gamal El-Dien O, Ratcliffe B, Klápště J, Chen C, Porth I, El-Kassaby YA (2015) Prediction accuracies for growth and wood attributes of interior spruce in space using genotyping-by-sequencing. BMC Genomics 16:370, 16 p. https://doi.org/10.1186/s12864-015-1597-y

Gouvernement du Québec (2000) L'amélioration génétique des arbres au Québec. Québec, Québec. $21 \mathrm{p}$

Gouvernement du Québec (2018) Guide d'analyse économique appliquée aux investissements sylvicoles. Bureau de mise en marché des bois, Gouvernement du Québec, Québec. $63 \mathrm{p}$
Gregersen H, Contreras A (1992) Economic assessment of forestry project impacts. Food and Agriculture Organization of the United Nations, Rome. FAO Forestry Paper 106. $134 \mathrm{p}$

Gregory GR (1987) Resource economics for foresters. Wiley, New York, $477 \mathrm{p}$

Groupe DDM (2009) Enquête sur les coûts de la sylviculture des forêts du domaine de l'État : 2007-2008. Rapport présenté au Ministère des Forêts, de la Faune et des Parcs du Québec, Gouvernement du Québec, Québec. 85 p

Groupe DDM (2016) Enquête 2014-2015 sur les coûts de la sylviculture en forêt publique. Rapport présenté au Ministère des Forêts, de la Faune et des Parcs du Québec, Gouvernement du Québec, Québec $44 \mathrm{p}$

Homagain K, Shahi CK, Luckai NJ, Leitch M, Bell FW (2011) Benefit cost analysis of vegetation management alternatives: an Ontario case study. For Chron 87:260-273. https://doi.org/10.5558/tfc2011-013

Ivković M, Wu HX, McRae TA, Matheson CA (2006) Developing breeding objectives for radiata pine structural wood production. II. Sensitivity analyses. Can J For Res 36:2932-2942. https://doi.org/ $10.1139 / \mathrm{x} 06-162$

Jansson G, Hansen JK, Haapanen M, Kvaalen H, Steffenrem A (2017) The genetic and economic gains from forest tree breeding programmes in Scandinavia and Finland. Scand J For Res 32:273286. https://doi.org/10.1080/02827581.2016.1242770

Klimaszewska K, Trontin J-F, Becwar MR, Devillard C, Park Y-S, LeluWalter M-A (2007) Recent progress in somatic embryogenesis of four Pinus spp. Tree Sci Biotechnol 1:11-25

Labbé F, Lainesse M, Nadeau F-R, Prégent G, Savary A (2014) Analyse de rentabilité économique des plantations d'épinette noire et blanche et de pin gris. Gouvernement du Québec, Bureau de mise en marché des bois, Québec $49 \mathrm{p}$

Laflèche V, Larouche F, Guillemette F (2013) Chapitre 15 - L'éclaircie commerciale. In Le guide sylvicole du Québec -Tome 2 - Les concepts et l'application de la sylviculture. Les Publications du Québec, Québec, pp 300-327

Leech J (2014) Rotation length and discount rates. Aust For 77:114-122. https://doi.org/10.1080/00049158.2014.945110

Lelu-Walter MA, Thompson D, Harvengt L, Sanchez L, Toribio M, Pâques LE (2013) Somatic embryogenesis in forestry with a focus on Europe: state-of-the-art, benefits, challenges and future direction. Tree Genet Genomes 9:883-899. https://doi.org/10.1007/s11295013-0620-1

Lenz P, Auty D, Achim A, Beaulieu J, Mackay J (2013) Genetic improvement of white spruce mechanical wood traits-early screening by means of acoustic velocity. Forests 4:575-594. https://doi.org/10. 3390/f4030575

Lenz PRN, Beaulieu J, Mansfield SD, Clément S, Desponts M, Bousquet J (2017) Factors affecting the accuracy of genomic selection for growth and wood quality traits in an advanced-breeding population of black spruce (Picea mariana). BMC Genomics 18:335, 17 p. https://doi.org/10.1186/s12864-017-3715-5

Lenz PRN, Nadeau S, Mottet M-J, Perron M, Isabel N, Beaulieu J, Bousquet J (2019) Multi-trait genomic selection for weevil resistance, growth and wood quality in Norway spruce. Evol Appl In press. (19 p.) doi: https://doi.org/10.1111/eva.12823

Li Y, Dungey HS (2018) Expected benefit of genomic selection over forward selection in conifer breeding and deployment. PLoS One 13: e0208232, 21 p. https://doi.org/10.1371/journal.pone.0208232

Li P, Beaulieu J, Bousquet J (1997) Genetic structure and patterns of genetic variation among populations in eastern white spruce (Picea glauca). Can J For Res 27:189-198

McKeand SE, Abt RC, Allen L, Li B, Catts GP (2006) What are the best loblolly pine genotypes worth to landowners? J For 104:352-358. https://doi.org/10.3723/175605496783333406 
McKenney D, Fox G, van Vuuren W (1992) An economic comparison of black spruce and jack pine tree improvement. For Ecol Manag 50: $85-101$

McWilliams E (2015) Genomic selection vs traditional breeding. Financial model for western redcedar and Douglas-fir. Report to Ministry of Forests, Lands and Natural Resource Operations Tree Improvement Branch \& Genome BC, Vancouver, British Columbia. $25 \mathrm{p}$

Meuwissen THE, Hayes BJ, Goddard ME (2001) Prediction of total genetic value using genome-wide dense marker maps. Genetics 157:1819-1829

Ministère des Resources naturelles et de la Faune du Québec (2011) Pépinière de Saint-Modeste. 50 ans à cultiver l'avenir en équipe 1961-2011. Gouvernement du Québec, Québec. 91 p

Mullin TJ, Andersson B, Bastien JC, Beaulieu J, Burdon RD, Dvorak WS, King JN, Kondo T, Krakowski J, Lee SJ, McKeand SE, Pâques L, Raffin A, Russell JH, Skroppa T, Stoehr M, Yanchuk A (2011) Economic importance, breeding objectives and achievements. In: Plomion C, Bousquet J, Kole C (eds) Genetics, Genomics and Breeding of Conifers. Science Publishers and CRC Press, New York, pp. $40-127$

Park Y-S (2002) Implementation of conifer somatic embryogenesis in clonal forestry: technical requirements and deployment considerations. Ann For Sci 59:651-656. https://doi.org/10.1051/forest: 2002051

Park Y-S, Weng Y, Mansfield SD (2012) Genetic effects on wood quality traits of plantation-grown white spruce (Picea glauca) and their relationships with growth. Tree Genet Genomes 8:303-311. https://doi.org/10.1007/s11295-011-0441-z

Park Y-S, Beaulieu J, Bousquet J (2016) Multi-varietal forestry integrating genomic selection and somatic embryogenesis. In: Park Y-S, Bonga JM, Moon H-K (eds) Vegetative propagation of Forest trees. National Institute of Forest Science, Seoul, pp. 302-322

Petrinovic J, Gélinas N, Beaulieu J (2009) Benefits of using genetically improved white spruce in Québec: the forest landowner's viewpoint. For Chron 85:571-582. https://doi.org/10.5558/tfc85571-4

Prégent G (2003) Caractéristiques des arbres coupés et du peuplement résiduel à la première éclaircie commerciale de plantations résineuses. Gouvernement du Québec, Québec. Mémoire de recherche forestière no. $143.54 \mathrm{p}$

Prégent G, Picher G, Auger I (2010) Tarif de cubage, tables de rendement et modèles de croissance pour les plantations d'épinette blanche au Québec. Gouvernement du Québec, Québec. Mémoire de recherche forestière no. $160.73 \mathrm{p}$

Pukkala T, Lähde E, Laiho O (2014) Stand management optimization the role of simplifications. For Ecosyst 1:3, (11 p.) https://doi.org/ 10.1186/2197-5620-1-3

Sedjo RA (2002) Biotechnology for planted forests: an assessment of biological, economic and environmental possibilities and limitations. In: Swanson T (ed) The economics of managing biotechnology. Kluwer Academic Publishers, Amsterdam, pp 71-95
Sorensson C (2006) Varietal pines boom in the US South. New Zeal J For $51: 34-40$

Tahvonen O, Pihlainen S, Niinimäki S (2013) On the economics of optimal timber production in boreal Scots pine stands. Can J For Res 43: 719-730. https://doi.org/10.1139/cjfr-2012-0494

Talbert JT, Weir RJ, Arnold RD (1985) Costs and benefits of a mature first-generation loblolly pine tree improvement program. J For 83: 162-166. https://doi.org/10.3723/1756054967833333406

Thiffault N, Hébert F (2013) Chapitre 13 - Le dégagement et le nettoiement. In Le guide sylvicole du Québec, Tome 2 - Les concepts et l'application de la sylviculture. Les Publications du Québec, Québec, pp 244-271

Thiffault N, Roy V (2011) Living without herbicides in Québec (Canada): historical context, current strategy, research and challenges in forest vegetation management. Eur J For Res 130:117-133. https://doi.org/ 10.1007/s10342-010-0373-4

Thiffault N, Roy V, Prégent G, Cyr G, Jobidon R, Ménétrier J (2003) La sylviculture des plantations résineuses au Québec. Nat Can 127:6380

Thiffault N, Roy V, Ménétrier J, Prégent G, Rainville A (2013) Chapitre 11 - La plantation. In Le guide sylvicole du Québec, Tome 2 - Les concepts et l'application de la sylviculture. Les Publications du Québec, Québec, pp 196-225

Thompson DG, Pitt DG (2003) A review of Canadian forest vegetation management research and practice. Ann For Sci 60:559-572. https:// doi.org/10.1051/forest

Tremblay L, Lamhamedi MS (2006) Embryogenèse somatique au ministère des Ressources naturelles et de la Faune du Québec: du laboratoire au site de plantation. Des Plants et des Hommes 9:6-11

Van Deusen PC, Bently Wigley T, Lucier AA (2010) Some indirect costs of forest certification. Forestry 83:389-394. https://doi.org/10.1193/ forestry/cpq021

Vogel B (2009) Marker-assisted selection: a non invasive biotechnology alternative to genetic engineering of plant varieties. Greenpeace International, Amsterdam, The Netherlands, $27 \mathrm{p}$

Wyatt S, Rousseau MH, Nadeau S, Thiffault N, Guay L (2011) Social concerns, risk and the acceptability of forest vegetation management alternatives: insights for managers. For Chron 87:274-289. https:// doi.org/10.5558/tfc2011-014

Zhang SY, Koubaa A (2008) Softwoods of Eastern Canada: their silvics, characteristics, manufacturing and end-uses. FPInnovations Forintek Division, Vancouver, British Columbia, Canada, Spec. Publ. SP-526E

Zhang D, Pearse PH (2012) Forest economics. UBC press., Vancouver, Canada, p 412

Publisher's note Springer Nature remains neutral with regard to jurisdictional claims in published maps and institutional affiliations. 